\title{
Overexpression of hepatoma-derived growth factor in melanocytes does not lead to oncogenic transformation
}

\author{
Angela Sedlmaier ${ }^{1}$, Nicolas Wernert ${ }^{2}$, Rainer Gallitzendörfer ${ }^{1}$, Mekky M Abouzied ${ }^{3}$, Volkmar Gieselmann ${ }^{1}$ and \\ Sebastian Franken ${ }^{1 *}$
}

\begin{abstract}
Background: HDGF is a growth factor which is overexpressed in a wide range of tumors. Importantly, expression levels were identified as a prognostic marker in some types of cancer such as melanoma.

Methods: To investigate the presumed oncogenic/transforming capacity of HDGF, we generated transgenic mice overexpressing HDGF in melanocytes. These mice were bred with mice heterozygous for a defective copy of the Ink4a tumor suppressor gene and were exposed to UV light to increase the risk for tumor development both genetically and physiochemically. Mice were analyzed by immunohistochemistry and Western blotting. Furthermore, primary melanocytes were isolated from different strains created.

Results: Transgenic animals overexpressed HDGF in hair follicle melanocytes. Interestingly, primary melanocytes isolated from transgenic animals were not able to differentiate in vitro whereas cells isolated from wild type and HDGF-deficient animals were. Although, $\mathrm{HDGF}^{-/} / \mathrm{Ink} \mathrm{a}^{+/-}$mice displayed an increased number of epidermoid cysts after exposure to UV light, no melanomas or premelanocytic alterations could be detected in this mouse model.

Conclusions: The results therefore provide no evidence that HDGF has a transforming capacity in tumor development. Our results in combination with previous findings point to a possible role in cell differentiation and suggest that HDGF promotes tumor progression after secondary upregulation and may represent another protein fitting into the concept of non-oncogene addiction of tumor tissue.
\end{abstract}

\section{Background}

HDGF is a heparin-binding growth factor originally isolated from conditioned medium of $\mathrm{HuH}-7$ cells $[1,2]$. Several studies reported that HDGF promotes proliferation, differentiation, and migration of several cell types, such as vascular smooth muscle cells, when applied exogeneously to the culture medium or when overexpressed endogeneously [3-6]. Studies revealed that HDGF is expressed in most organs (liver, brain, lung, intestine etc.) both during embryonic development and throughout the organism's life [7]. Together with its mitogenic activity HDGF was therefore implicated in organ development and tissue differentiation [5,8,9]. Models of

\footnotetext{
* Correspondence: franken@ibmb.uni-bonn.de

'Institute of Biochemistry and Molecular Biology, University of Bonn, Nussallee 11, 53115 Bonn, Germany

Full list of author information is available at the end of the article
}

vascular injury and ulcerative colitis pointed towards a function of HDGF in tissue repair [10-12]. This suggestion was supported by the classification of HDGF as an alarmin, a protein signaling cell and tissue damage to the immune system $[13,14]$. Surprisingly, HDGF-knockout $\left(\mathrm{HDGF}^{-1-}\right)$ mice are viable and show no developmental phenotype [15]. Over the last years, the overexpression of HDGF in various tumors attracted more and more attention. Up to now HDGF has been reported to be overexpressed in non-small cellular lung cancer [16], hepatocellular carcinoma $[17,18]$, colorectal carcinoma [19,20], oesophagal carcinoma [21], pancreatic carcinoma [22] and melanoma [23]. Furthermore, a correlation between the degree of HDGF overexpression and the course of disease was found for some types of cancer, including melanoma, leading to the classification of HDGF as a novel prognostic marker [16,18,20-22,24].
C Biomed Central

() 2011 Sedlmaier et al; licensee BioMed Central Ltd. This is an Open Access article distributed under the terms of the Creative Commons Attribution License (http://creativecommons.org/licenses/by/2.0), which permits unrestricted use, distribution, and reproduction in any medium, provided the original work is properly cited. 
In addition, several studies suggested a role for HDGF in tumor angiogenesis [25,26], metastasis [19,26], and apoptosis $[27,28]$. So far, the influence of HDGF on tumors was studied by si-RNA mediated or antibodymediated reduction of HDGF in tumor mouse models. The accordant results showed, that a reduction of HDGF in tumor cells resulted in the formation of smaller tumors, reduced tumor angiogenic and metastatic capacity, and an improved response to chemotherapeutic treatment $[25,26]$. However, a direct influence of an initial overexpression of HDGF has so far not been investigated.

In this study, we present for the first time results on the presumed putative oncogenic/transforming capacity of this mitogenic growth factor by studying the influence of HDGF on tumor development in a transgenic mouse model overexpressing HDGF in melanocytes, a cell type from which malignant melanoma, a highly aggressive type of cancer, arises. This model was generated to study the influence of HDGF-overexpression in a non-transformed cell type in vivo.

\section{Methods}

\section{Construction of the Tyrosinase(Tyr)-HDGFgene construct}

The Tyr-HDGFgene construct consists of the complete HDGF genomic sequence, except for intronI which was shortened from 6, 377 bp to $786 \mathrm{bp}$. The shortened HDGF gene was cloned into the phs3.6 Tyrosinase-lacZ $(-6.1)$ vector (kindly provided by Friedrich Beermann, IRES, Epalinges, Switzerland) in multiple steps. First, the lacZ gene was removed by incubating the vector with the restriction enzymes SmaI and NotI (Fermentas, St. Leon-Rot, Germany). Before the plasmid was allowed to religate, the ends were blunted by using the Klenow Fragment (Fermentas, St. Leon-Rot, Germany). In a second step, this plasmid was linearized through incubation with XhoI and ligated with the compatible ends of the SalI incubated shortened HDGF gene.

\section{Generation of Transgenic Mice}

The HDGF ${ }^{\mathrm{Tyr}}$-transgenic mice were generated through injection of the Tyr-HDGFgene construct into the pronucleus of fertilized eggs. The genotype of the emanated mice and their offspring was determined by PCR on DNA from tail biopsies. The following primers were used to distinguish the Tyr-HDGFgene construct from the wildtype HDGF gene: mHDGFgeneConstruct_sense, 5'-GTATCGATAAGCTTGGTACCATG-3' and HDGFwt-antisense, 5'-CTTGGTATTTGTTGGC TGTTGA-3'. PCR conditions were as follows: denaturation for $3 \mathrm{~min}$ at $95^{\circ} \mathrm{C}$, followed by 35 cycles of $30 \mathrm{sec}$ at $95^{\circ} \mathrm{C}, 60 \mathrm{sec}$ at $54^{\circ} \mathrm{C}$ and $60 \mathrm{sec}$ at $72^{\circ} \mathrm{C}$. This reaction resulted only in a fragment of $943 \mathrm{bp}$ if the TyrHDGFgene construct was present in the sample DNA.
All mice were backcrossed for more than ten generations into the C57BL6N background. Furthermore, the following mouse lines were generated by backcrossing: $\mathrm{HDGF}^{\mathrm{Tyr}} / \mathrm{HDGF}^{-/-}$, $\mathrm{HDGF}^{\mathrm{Tyr}} / \mathrm{Ink} 4 \mathrm{a}^{-/-}, \mathrm{HDGF}^{-/-} / \mathrm{Ink}_{4} \mathrm{a}^{-/-}$. The $\mathrm{HDGF}^{-/-}$mouse line was generated by Rainer Gallitzendörfer (IBMB, University of Bonn, Germany) [15], whereas the Ink $4 \mathrm{a}^{-1-}$ mice were kindly provided by Clemens Schmitt (Charité - University Berlin, Germany) with permission of Manuel Serrano (Spanish National Cancer Research Centre, Madrid, Spain) [29].

Mice used in this study were housed under standard conditions in a 12 hour light-dark cycle and provided with food and water ad libitum. All experiments were carried out in accordance with local and state regulations for animal research.

\section{Southern Blot Analysis}

Genomic DNA was isolated from mouse tails by phenol/ chloroform extraction. $10 \mu \mathrm{g}$ DNA was fragmented by incubation with the restriction enzymes BglII and HindIII (Fermentas, St. Leon-Rot, Germany), separated on a $0.8 \%$ agarose gel and blotted onto a Hybond ${ }^{\mathrm{TM}}-\mathrm{N}^{+}$nylon filter (Amersham, GE Healthcare, Munich, Germany) by performing a capillary blot. The probe spanning exonIV, intronIV and exonV of the HDGF gene was labeled with $\left[\alpha^{32} \mathrm{P}\right]$-dCTP by using the Megaprime-DNA labeling Kit $^{\circledR}$ (Amersham, GE Healthcare, Munich, Germany) according to manufacturer's instruction. Hybridization was carried out by incubating the membrane in FBI-buffer (SSPE buffer, 10\% PEG-8000, 7\% SDS) containing the radioactive labeled probe $\left(1 \times 10^{6} \mathrm{cpm}\right.$ per $\mathrm{cm}^{2}$ filter). Signals were detected by exposing the filters to films (Kodak, Stuttgart, Germany) for 24 hours.

\section{UVB-Irradiation of newborn mice}

Mice of 1-3 days of age were placed on a sterile cotton sheet and irradiated with a single UVB-dose of $6.14 \mathrm{~kJ} /$ $\mathrm{m}^{2}$. The light pannel contained four TL/12 UVB-light bulbs. The dose was determinded by a scanning spectrophotometer. The following genotypes were used for this experiment: $\mathrm{HDGF}^{\mathrm{Tyr}} / \mathrm{INK} 4 \mathrm{a}^{+/-}, \operatorname{Ink} 4 \mathrm{a}^{+/-}, \mathrm{HDGF}^{-/-}$ INK $4 \mathrm{a}^{+/-}$, $\mathrm{HDGF}^{\mathrm{Tyr}}$, wildtype and $\mathrm{HDGF}^{-/-}$.

\section{Isolation of total RNA and RT-PCR}

Total RNA was isolated using Trizol (Invitrogen), following the manufacturer's instructions. cDNA was synthesized from $1 \mu \mathrm{g}$ total RNA using QuantiTect Reverse Transcription Kit (Qiagen) according to the manual. For the detection of HDGF-cDNA a PCR with primer HDGF-sense (5'GCGGCGGTACCATGTCGCGATCCAACCGG3') and HDGF-antisense (5' GAGACTCGAGT GAGTGAGGGAGTAG3'), and REDTaq $^{\circledR}$ ReadyMix ${ }^{\text {TM }}$ PCR Reaction Mix (Sigma) was performed following the manufacturer's instructions. To 
specifically amplify the HDGF-cDNA expressed from the Tyr-HDGFgene construct the primers mHDGFgeneConstruct_sense (5'GTATCGATAAGCTTGGTACCATG3') and HDGF-antisense (5'GAGACTCGAGTGAGTGAGGGAGTAG3') were used. PCR conditions were as follows: denaturation for $3 \mathrm{~min}$ at $95^{\circ} \mathrm{C}$, followed by 35 cycles of $30 \mathrm{sec}$ at $95^{\circ} \mathrm{C}$, $60 \mathrm{sec}$ at $56^{\circ} \mathrm{C}$ and $60 \mathrm{sec}$ at $72^{\circ} \mathrm{C}$.

\section{Immunostaining and Histology}

Tissue sections were prepared from skin samples from each group of mice and for each treatment. Tissues were fixed at $4^{\circ} \mathrm{C}$ over night ( $4 \%$ buffered formalin/10\% sucrose), paraffin embedded and cut into $4 \mu \mathrm{m}$ sections. HE staining was performed as previously described [30]. Sections were deparaffinized in $10 \mathrm{mM}$ Citrate-buffer, pH 6.0 and blocked with 3\% BSA/TBS. Affinity-purified polyclonal rabbit-anti-mouse HDGF (dilution 1:100 in 1\% BSA/TBS) antibodies (Abouzied et al., 2004) were used to stain mouse tissue. Control slides were incubated with 1\% NGS/TBS (normal goat serum (Abcam) in TBS) without primary antibody. For immunofluorescent detection of HDGF, goat-anti-rabbit-Cy3 was used as a secondary antibody. Nuclei were stained with DAPI (Sigma). Images were aquired on an Axioskop 2 MOT (Carl Zeiss, Jena, Germany) microscope equipped with an Olympus XL-50 (Olympus, Hamburg, Germany) digital camera.

\section{Bleaching of pigmented Tissue sections}

Bleaching of tissue sections was carried out after deparaffinization in a solution consisting of 55\% benzyl alcohol, $25 \%$ acetone, $15 \% \mathrm{H}_{2} \mathrm{O}_{2}(10 \%)$ and $5 \%$ ammonium hydroxide solution (25\%). According to the grade of pigmentation incubation time ranged from 15-120 min at $37^{\circ} \mathrm{C}$.

\section{In Situ Hybridisation}

For the detection of tyrosinase mRNA a tyrosinase sense (Tyr_s - control) and antisense (Tyr_as - experimental) probe were generated from C57BL6 skin cDNA (Primer: Tyr_sense 5'-AGTCTGCAG TACTCGAGTGTTTTGTATTGCCTTCTGTGGA-3'; Tyr_antisense 5'TGAAGCTTACCCATT GTTCATTTGGCCAT-3') and transcribed on a T7-based plasmid using a digoxigenin (DIG) RNA-labeling kit (Roche Applied Science, Manheim, Germany) according to the manufacturer's manual. Four micrometer sections were cut from paraffine embedded skin samples and adhered to glass slides (Superfrost Ultra Plus, Thermo Fisher Scientific, Waltman, MA). In situ hybridization was performed as previously described by Fewou and coworkers [31]. Briefly, after rehydration, sections were post-fixed in $4 \%$ paraformaldehyde/PBS, before endogenous peroxidases were inhibited by incubation with $1 \% \mathrm{H}_{2} \mathrm{O}_{2} / \mathrm{PBS}$ for 15 min. Thereafter, sections were treated with proteinase $\mathrm{K}$ (10 $\mu \mathrm{g} / \mathrm{ml} ; 4 \mathrm{~min})$ and permeabilized with $0.25 \%$ Triton $\mathrm{X}$ 100 (4 min). Afterwards, the slices were incubated with $0.2 \mathrm{M} \mathrm{HCl}$ (8 min), $0.1 \mathrm{M}$ triethanolamine $/ 2.5 \mu \mathrm{l} / \mathrm{ml}$ acetic anhydride $(10 \mathrm{~min})$, and washed for $10 \mathrm{~min}$ with $2 \times \operatorname{SSC}(0.15 \mathrm{M} \mathrm{NaCl} / 0.015 \mathrm{M}$ sodium citrate $)$ at $50^{\circ} \mathrm{C}$. DIG-labeled probes (diluted 1:1, 000 in $50 \%(\mathrm{v} / \mathrm{v})$ formamide, $1 \%$ Denhardt's solution, $0.2 \%$ SDS, and $10 \%(\mathrm{w} / \mathrm{v})$ hybridization salt ( $3 \mathrm{M} \mathrm{NaCl}, 0.1 \mathrm{M}$ PIPES and $0.1 \mathrm{M}$ EDTA)) were allowed to hybridize to tissue-mRNA over night at $70^{\circ} \mathrm{C}$. After removal of the hybridization solution, sections were washed with $2 \times \mathrm{SSC}$ at $60^{\circ} \mathrm{C}$, for 20 min with $50 \%$ formamide $/ 1 \times \mathrm{SSC}$ at $60^{\circ} \mathrm{C}$ and for 45 min with $0.1 \times \mathrm{SSC}$ at $70^{\circ} \mathrm{C}$. DIG-labeled probes were detected by incubation with alkaline phosphatase-conjugated anti-DIG $\mathrm{F}_{\mathrm{ab}}$ fragment (Roche Applied Science, Manheim, Germany). Bound antibodies were further visualized by incubating the slides with BMPurple ${ }^{\mathrm{TM}}$ (Roche Applied Science, Manheim, Germany) for 7-10 days. Color development was stopped by washing with $\mathrm{dd}_{2} \mathrm{O}$, before embedding the slides with Mowiol. Images were aquired on an Axioskop 2 MOT (Carl Zeiss, Jena, Germany) microscope equipped with an Olympus XL-50 (Olympus, Hamburg, Germany) digital camera.

\section{Primary Melanocyte Culture}

1-3 day old mice were used for the isolation of melanocytes. Neonatal mice were decapitated and desinfected, before the abdominal skin was drawn off. The whole skin was incubated overnight in dispase II-solution (5 $\mathrm{mg} / \mathrm{ml} ; 4^{\circ} \mathrm{C}$; slightly shaking) before the epidermis could be separated from the dermis. Dissociation of the epidermal cells was achieved by incubation of the epidermis floating on $1 \mathrm{ml}$ trypsin solution (0.025\% trypsin/ $0.02 \%$ EDTA/PBS; 5 min; room temperature) with the stratum corneum facing up. The reaction was stopped by adding $3 \mathrm{ml}$ of FCS containing medium and the epidermal cells could subsequently be detached by gentle scraping with a spattle. The cell suspension was sedimented by centrifugation $(600 \times$ g; 5 min; room temperature), before the cells were resuspended in fresh melanocyte medium (RPMI Gibco BRL including 5\% FCS (Invitrogen), 2 mM Glutamax ${ }^{\mathrm{TM}}$ (Gibco BRL), 100 IU penicillin (Gibco BRL), $100 \mu \mathrm{g}$ streptomycin (Gibco BRL), $4 \mu \mathrm{g} / \mathrm{ml}$ insulin (Sigma), $100 \mathrm{U} / \mathrm{ml}$ catalase (Sigma), $10 \mu \mathrm{g} / \mathrm{ml} \mathrm{BPE} \mathrm{(Sigma))} \mathrm{and} \mathrm{seeded} \mathrm{into} \mathrm{a} 10$ $\mathrm{cm}$ cell culture dish. After four days the keratinocytes made up a confluent cell layer on which the melanocytes grew. The melanocytes were detached from the keratinocytes by trypsinization for $1 \mathrm{~min}$. The cells were sedimented and resuspended in melanocyte medium supplemented with $23 \mathrm{ng} / \mathrm{ml}$ 3-isobutyl-1- 
methylxanthen (IBMX), $100 \mathrm{ng} / \mathrm{ml}$ 12-O-tetradecanoylphorbol-13-acetate (TPA). Medium was replaced every three days.

\section{Western Blot Analysis}

Tissue samples and cell pellets were lysed in HEPES buffer (20 mM HEPES/OH pH 7.4, $250 \mathrm{mM}$ sucrose, 10 $\mathrm{mM} \mathrm{KCl,} 1.5 \mathrm{mM} \mathrm{MgCl}$, $1 \mathrm{mM}$ EDTA, $1 \mathrm{mM}$ EGTA, 1 mM PMSF, 1 mM DTT, $50 \mu \mathrm{g} / \mathrm{ml}$ DNaseI, 0.1\% SDS (v/ v), $1 \mu \mathrm{g} / \mathrm{ml}$ leupeptin, $1 \mu \mathrm{g} / \mathrm{ml}$ pepstatin). The lysates were incubated on ice for 20 minutes followed by centrifugation at $18,000 \times \mathrm{g}$ and $4^{\circ} \mathrm{C}$ for $20 \mathrm{~min}$. The protein concentration of the supernatant was determined by using the Bio-Rad DC protein assay system (Bio-Rad Laboratories, Munich, Germany) according to the manufacturer's instructions. Soluble homogenates $(40 \mu \mathrm{g}$ total protein) were separated under denaturating conditions in $10 \%$ sodium dodecyl sulfate-polyacrylamide gels by electrophoresis and transferred onto pvdf-membranes (BioRad, Munich, Germany) using semidry blotting [32]. Membranes were stained with Coomassie solution (Coomassie Brilliant Blue R, Serva 35051) to assess equal loading and destained (Destaining solution: 5\% methanol, 7\% acetic acid in $\mathrm{H}_{2} \mathrm{O}$ ) afterwards. Thereafter, membranes were blocked with $5 \%$ skim milk/TBS, followed by incubation with affinity-purified polyclonal rabbit-anti-mouse HDGF antibody solution (dilution 1:1, 000) [7]. Subsequently, membranes were incubated with a goat-anti-rabbit IgG conjugated to horseradish peroxidase (dilution 1:10, 000) (Dianova, Hamburg, Germany). Immunoreactive proteins were visualized with enhanced chemiluminescence (Pierce ECL Western Blotting Substrate, Pierce, Rockford, IL) and exposure to films (Kodak, Stuttgart, Germany) according to manufacturer's instruction.

\section{Statistical Analysis}

Statistical analysis of the epidermoid cysts was carried out by applying a chi-square contingency table test.

\section{Results}

Generation and genotyping of transgenic mice (HDGF ${ }^{\mathrm{Tyr}}$ ) To investigate whether HDGF exhibits oncogenic/transforming capacities and whether the observed HDGFoverexpression in various types of tumors promotes tumor development and/or progression, a mouse model was generated overexpressing HDGF only in melanocytes. To allow the expression of possible alternative splicing products we constructed a transgene containing all exons and introns of the murine HDGF gene with a shortened intronI (HDGFgene; Figure 1A). To test the integrity of the protein expressed from this construct it was first cloned under the control of a CMV promoter and expressed in HEK cells. Western blot analysis of cell lysates confirmed the expression of two protein variants at molecular weights resembling HDGF protein variants (Additional file 1A) as can be observed in several tissues [7]. To target the expression to pigment cells, the HDGFgene construct was further cloned under the control of the tyrosinase promoter/enhancer element driving the expression of the melanocyte-specific protein tyrosinase (Figure 1A). Linearized and purified plasmidDNA was used for pronuclear injection. Out of 61 offspring, 15 were initially genotyped positive for the integration of the Tyr-HDGFgene construct by PCRgenotyping. Figure 1B shows exemplarily the PCR result for the offspring 7159 and 889. In case of an integration of the Tyr-HDGFgene construct, a $943 \mathrm{bp}$ fragment was amplified, which was absent in the wildtype-DNA control. The integration was confirmed by performing a Southern blot (Figure 1C). Due to fragmentation of the genomic DNA with the restriction enzymes BglII and HindIII, two DNA-fragments could be detected with the help of the radioactivly labeled probe encompassing exo$\mathrm{nIV}$, intronIV and exonV. The 4, $386 \mathrm{bp}$ fragment, representing the wildtype allele, could be detected in all samples, whereas the 2, $570 \mathrm{bp}$ fragment representing the Tyr-HDGFgene construct was only detected in the samples of the offspring 7159 and 889 but not in the samples of offspring 7165 and the wildtype control. Offspring 7159 and 889 were used as founders for two independent transgenic mouse lines.

\section{Analysis of $\mathrm{HDGF}^{\mathrm{Tyr}}$ mice}

Tyrosinase-HDGF (HDGF ${ }^{\mathrm{Tyr}}$ ) transgenic mice were viable, fertile, and neither showed defects in pigmentation nor did they prematurely turn gray. HDGF expression in skin samples of $\mathrm{HDGF}^{\mathrm{Tyr}}$ mice was first compared to that of wildtype mice by immunfluorescence (Figure 2A a, b, f, g). Staining of wildtype hair follicles revealed a nuclear HDGF expression in cells of the hair follicle including the pigmented region (Figure 2A a, f). However, in $\mathrm{HDGF}^{\mathrm{Tyr}}$ mice a bright signal for HDGF was obtained in the pigmented area of the hair follicles (Figure 2A b, g). To ensure that the detected protein represents transgenic $\mathrm{HDGF}, \mathrm{HDGF}^{\mathrm{Tyr}}$ mice were backcrossed into the $\mathrm{HDGF}^{-/-}$mouse line. Indeed, immunfluorescent staining of skin samples from $\mathrm{HDGF}^{\mathrm{Tyr}} / \mathrm{HDGF}^{-/-}$(Figure $2 \mathrm{~A} \mathrm{c}, \mathrm{d}, \mathrm{h}, \mathrm{i}$ ) in comparison to $\mathrm{HDGF}^{-/}$(Figure 2A e, j) mice proofed that the distinct staining pattern seen in $\mathrm{HDGF}^{\mathrm{Tyr}}$ mice originates from the transcript of the Tyr-HDGFgene construct. In situ hybridization using a tyrosinase RNA probe demonstrates that the observed HDGF-staining pattern correlates with the localization of melanocytes in the pigmented area of the hair follicles (Additional file 2). To further investigate the expression of the TyrHDGFgene construct, RT-PCRs were performed on cDNA from brain, eye, skin samples (Additional file 


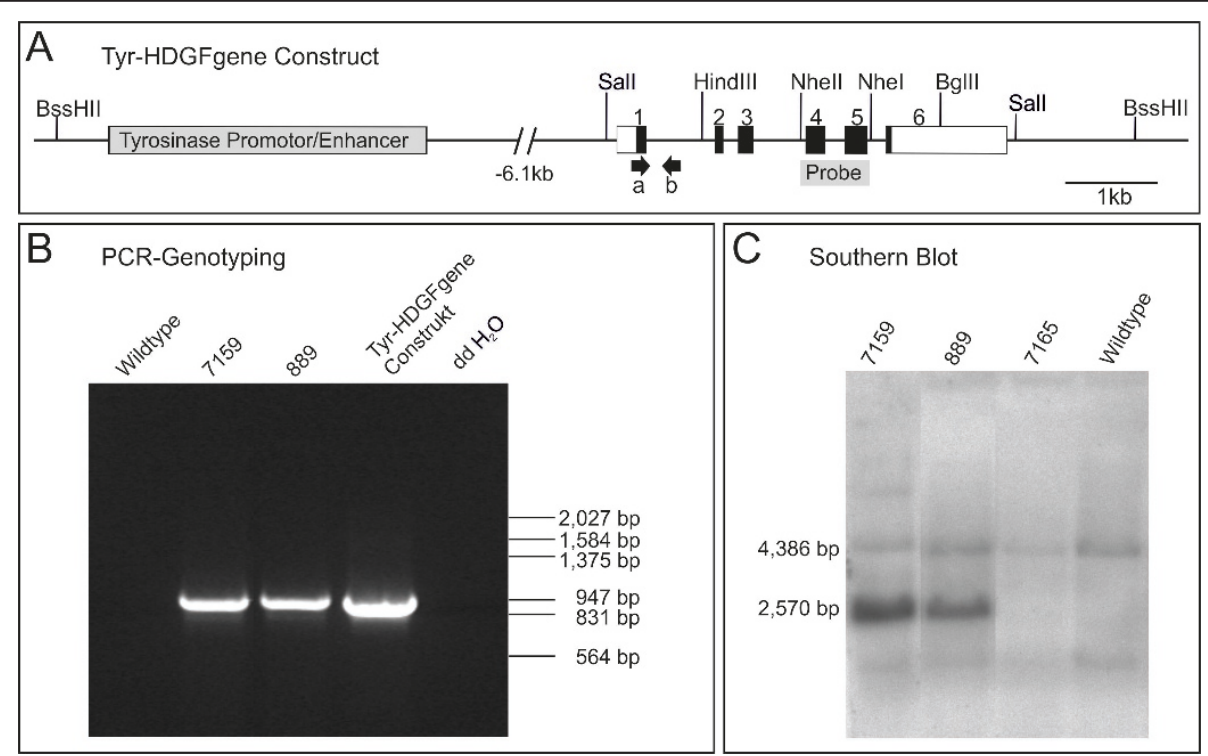

Figure 1 Generation of HDGF $^{\text {Tyr }}$ transgenic mice. A: Schematic map of the Tyrosinase-HDGFgene construct. The Tyrosinase Promotor/ Enhancer element is located approximately $6.1 \mathrm{~kb}$ in front of exonl. The HDGF gene consists of the complete exon/intron structure, except intronl was shortened from 6, $377 \mathrm{bp}$ to $786 \mathrm{bp}$. The construct was separated from the vector backbone by incubation with the restriction enzyme BssHII, purified, and injected into the pronucleus of fertilized mouse egg cells. Boxes 1-6 indicate exons (white parts represent noncoding, black parts indicate coding regions). Arrows show the site of primer annealing for PCR-genotyping. The probe used for Southern blot analysis spans exonIV, intronIV and exonV. B: Examples of a polymerase chain reaction (PCR) genotyping of mouse tail DNA. Primers a and b were used to amplify the $943 \mathrm{bp}$ fragment. Wildtype DNA was used as a negative control. $10 \mathrm{ng}$ of Tyr-HDGFgene construct plasmid DNA was used as a positive control. C: Exemplary illustration of a Southern blot analysis of mouse tail DNA from the PCR-positive offspring 7159 and 889 and the PCR-negative offspring 7165 and wildtype mouse tail DNA as a control. The radioactively labeled probe spanning exonIV, intronIV and exonV hybridizes to both fragments of the wildtype HDGF-allele (4, 386 bp) and the Tyr-HDGFgene construct (2, 570 bp).

1C). The construct was expressed in all three tissues (red arrows) showing strongest expression in the brain. This observation corresponds to an already known leakiness of the tyrosinase promoter in brain tissue [33-36]. Comparison of DNA sequences from the skin PCR-product of wildtype HDGF to transgenic HDGF revealed no mutations over the whole length of the transcript (data not shown). Western blot analysis of skin samples did not reveal significant differences between wildtype and transgenic animals (data not shown) most likely because melanocytes account for only $5-10 \%$ of mouse skin cells. Because the RT-PCR results confirmed the previously published leakiness of the Tyrosinase promoter/enhancer construct in the brain, a western blot analysis of brain lysates was performed (Additional file 1B). The result showed that in the brain of $\mathrm{HDGF}^{\mathrm{Tyr}} / \mathrm{HDGF}^{-/-}$ mice a HDGF protein could be detected migrating at the same height as HDGF from wildtype tissue (white arrow). To further investigate HDGF expression in melanocytes, primary melanocytes were isolated from neonatal skin of $\mathrm{HDGF}^{\mathrm{Tyr}}$, wildtype and $\mathrm{HDGF}^{-/-}$mice to quantify the elevated HDGF-expression in HDGF ${ }^{\text {Tyr }}$ melanocytes by immunofluorescent stainings. Wildtype and $\mathrm{HDGF}^{-1-}$ melanocytes grew in cell culture and differentiated into pigment producing melanocytes while forming a near confluent cell layer (Figure 2B b, c, e, f). Surprisingly, very few pigmented cells could be obtained from HDGF $^{\text {Tyr }}$ mice (arrows in Figure 2B a, d). However, Western blot analysis of primary melanocyte lysates revealed that wildtype melanocytes express no substantial amount of HDGF (Figure 2C), whereas HDGF could be detected in B16F10 mouse melanoma cell lysate. In addition HDGF could also not be detected in lysates from $\mathrm{HDGF}^{\mathrm{Tyr}}$ melanocyte cultures.

In summary, the strong HDGF signal in hair follicle melanocytes from HDGF ${ }^{\mathrm{Tyr}}$ and $\mathrm{HDGF}^{\mathrm{Tyr}} / \mathrm{HDGF}^{-1-}$ mice compared to wildtype and $\mathrm{HDGF}^{-/-}$ones, respectively as well as the overlapping HDGF-protein and tyrosinase-mRNA expression pattern confirmed that the generation of the $\mathrm{HDGF}^{\mathrm{Tyr}}$ transgenic mice resulted in an elevated HDGF-expression in hair follicle melanocytes. HDGF ${ }^{\mathrm{Tyr}}$ and wildtype mice were monitored over 24 month, but no effect of the additional HDGF could be observed in vivo. In particular, no melanocytic lesions or melanoma could be detected in $\mathrm{HDGF}^{\mathrm{Tyr}}$ mice.

\section{Analysis of $\mathrm{HDGF}^{\mathrm{Tyr}}$ mice under tumor growth promoting conditions}

To uncover the putative oncogenic/transforming capacity of $\mathrm{HDGF}, \mathrm{HDGF}^{\mathrm{Tyr}}$ and $\mathrm{HDGF}^{-/-}$mice were 

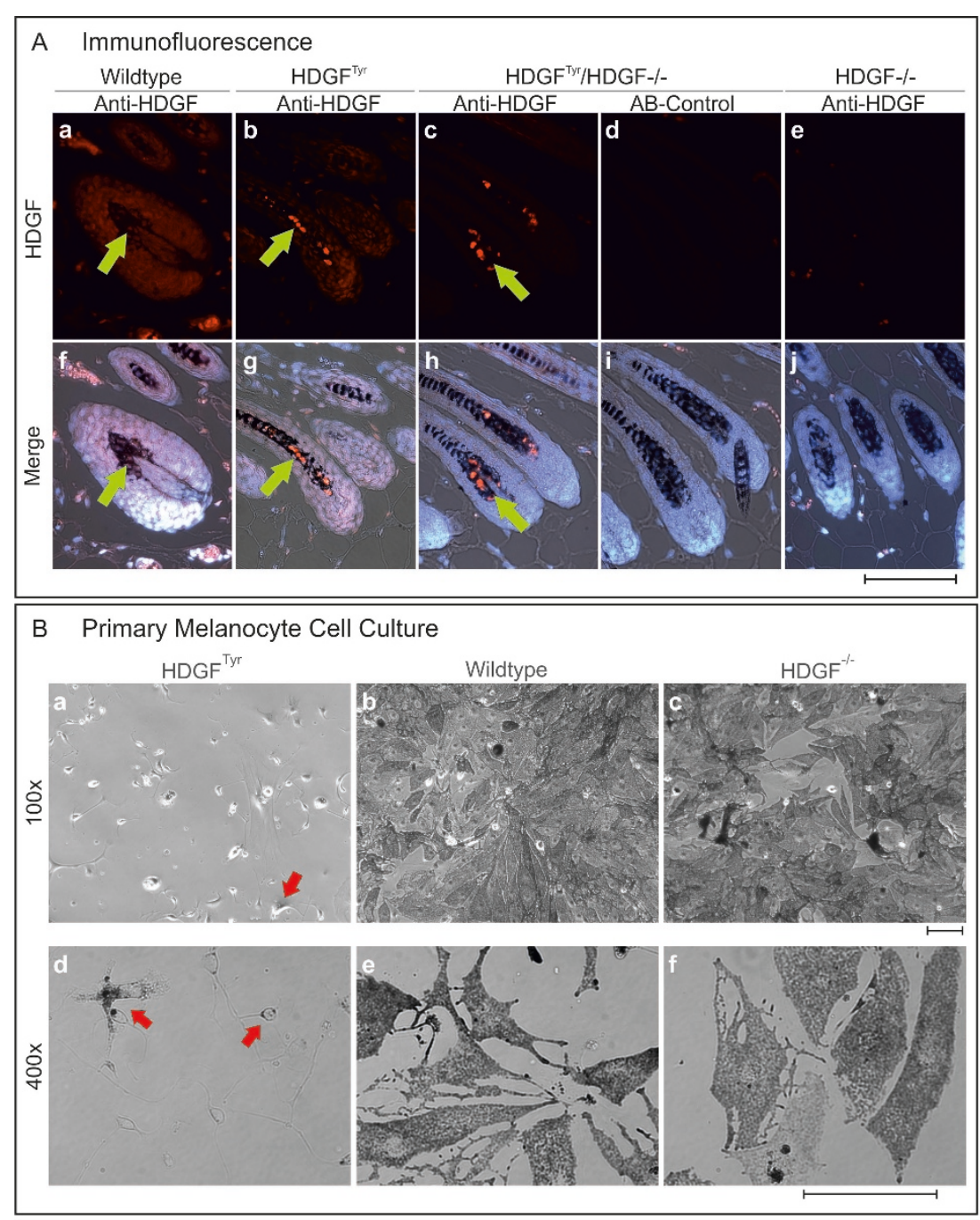

C Western Blot Analysis Of Melanocyte Lysates

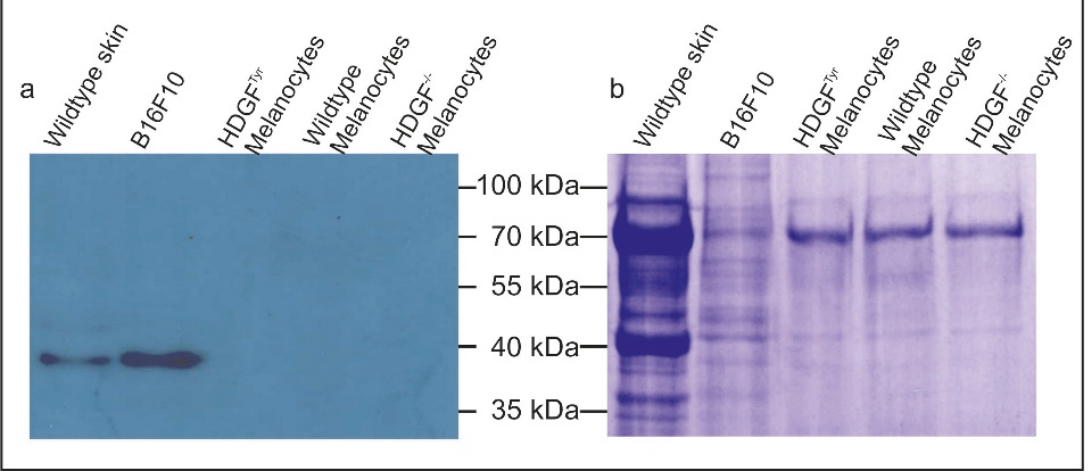

Figure 2 Detection of melanocyte-specific HDGF-overexpression. A: Immunofluorescence of skin samples from wildtype, HDGF ${ }^{T y r}$, HDGF ${ }^{T y r} /$ $\mathrm{HDGF}^{-1-}$ and $\mathrm{HDGF}^{-1-}$ mice. Paraffin sections were stained with affinity-purified anti-mouse HDGF antibody. Bound antibody was detected by incubation with Cy3 conjugated secondary anti-rabbit antibody. Nuclei were stained with DAPI. a-e HDGF; f-j merge of HDGF, DAPI and transmitted light. Green arrows point at HDGF positive melanocyte nuclei. Scale bar equates $100 \mu \mathrm{m}$. B: Primary melanocyte cell culture. Melanocytes were isolated from newborn $\mathrm{HDGF}^{\mathrm{Tyr}}$, wildtype and $\mathrm{HDGF}^{--}$mice. After 2-3 weeks melanocytes from wildtype and $\mathrm{HDGF}^{-/-}$mice grew in a sub-confluent cell layer, whereas very few melanocytes from HDGF $\mathrm{Hyr}^{\mathrm{T}}$ animals (red arrows) were able to survive in cell culture. a-c 100 $\times$ magnification; d-f $400 \times$ magnification. Scale bar equates $100 \mu \mathrm{m}$. C: Western blot analysis of melanocyte lysates. a HDGF-level of primary melanocytes from $\mathrm{HDGF}^{\mathrm{Tyr}}$, wildtype and $\mathrm{HDGF}^{-/}$mice was compared to the level of complete skin and B16F10 (murine melanoma cell line) lysates. $10 \mu \mathrm{g}$ total protein was loaded onto an SDS-gel. b Equal loading of melanocyte lysate was assessed by staining the membrane with Coomassie solution. 
backcrossed with Ink $4 \mathrm{a}^{-1-}$ mice (kindly provided by Clemens Schmitt (Charité - University of Berlin) with permission of Manuel Serrano [29]). These mice are cancer prone and develop lymphoma and sarcoma spontaneously. Although the Ink4a gene locus is mutated in about $40 \%$ of familiar melanoma, Ink $4 \mathrm{a}^{-1-}$ mice do not develop melanoma spontaneously [29]. But the introduction of an oncogene under the control of a melanocytespecific promoter like e.g. Tyr-HRas ${ }^{(\mathrm{G} 12 \mathrm{~V})}$ [37] or TyrTag [38] results in melanoma development. The emanated HDGF ${ }^{\mathrm{Tyr}} / \mathrm{Ink}_{4} 4 \mathrm{a}^{-1-}$, Ink $4 \mathrm{a}^{-1-}$ and $\mathrm{HDGF}^{-1-} / \mathrm{Ink} 4 \mathrm{a}^{-1-}$ mice were monitored over their reduced life span (5-12 month) and analyzed histologically. Again, the mice were viable, fertile, and showed no altered pigmentation pattern nor did they turn gray prematurely. In addition, no histological alterations concerning melanocyte number or location were observed. Therefore, $\mathrm{HDGF}^{\mathrm{Tyr}}$ / Ink $4 \mathrm{a}^{+/-}$, Ink $4 \mathrm{a}^{+/-}, \mathrm{HDGF}^{-1-} / \mathrm{Ink}_{4} \mathrm{a}^{+/}$, as well as $\mathrm{HDGF}^{\mathrm{Tyr}}$, wildtype, and $\mathrm{HDGF}^{-1-}$ mice were exposed to an additional mutagenic noxa. For this purpose, mice were neonatally exposed to a single UVB dose of $6.14 \mathrm{~kJ} / \mathrm{m}^{2}$ $[39,40]$. The 1-3 day old mice developed UV-erythema resulting in peeling off the skin after 6-8 days. After eight month animals of the genotypes $\mathrm{HDGF}^{\mathrm{Tyr}} / \mathrm{Ink} 4 \mathrm{a}$ +/-, Ink $4 \mathrm{a}^{+/-}, \mathrm{HDGF}^{-/-} / \mathrm{Ink} 4 \mathrm{a}^{+/-}$developed pigmented skin abnormalities (PSA) on tail and back skin, whereas no abnormalities could be observed in $\mathrm{HDGF}^{\mathrm{Tyr}}$, wildtype, and $\mathrm{HDGF}^{-/}$mice of up to 12 month after treatment. The PSA of each $\mathrm{HDGF}^{\mathrm{Tyr}} / \mathrm{Ink} 4 \mathrm{a}^{+/-}$, Ink $4 \mathrm{a}^{+/-}$, or $\mathrm{HDGF}^{-/-} / \mathrm{Ink}_{4} \mathrm{a}^{+/-}$mouse were counted, sizes were assessed and statistically evaluated (Figure 3B and 3C), before they were subjected for histological analysis. Figure 3A shows exemplary views of the inner side of the skin of $\mathrm{HDGF}^{\mathrm{Tyr}} / \mathrm{Ink}_{4} \mathrm{a}^{+/-}$, Ink $4 \mathrm{a}^{+/-}$, and $\mathrm{HDGF}^{-/-} / \mathrm{Ink} 4 \mathrm{a}$ $+/$ mice, exposing the highly pigmented lump. The graph shows that $\mathrm{HDGF}^{\mathrm{Tyr}} / \mathrm{Ink} 4 \mathrm{a}^{+/-}$and Ink $4 \mathrm{a}^{+/-}$mice developed comparable numbers and sizes of PSA, whereas $\mathrm{HDGF}^{-1-} / \mathrm{Ink}_{4 \mathrm{a}^{+/-}}$mice developed both more and larger PSA. These findings were further analyzed by applying a chi-square test to assess if the observed discrepancy was statistically significant (Figure 3C). Accordingly, $\mathrm{HDGF}^{-/-} / \mathrm{Ink}_{4 \mathrm{a}^{+/-}}$mice developed significantly more and larger PSA compared to both Ink $4 \mathrm{a}^{+/-}$ and $\mathrm{HDGF}^{\mathrm{Tyr}} / \mathrm{Ink} 4 \mathrm{a}^{+/-}$mice $(p<0.001)$. In contrast, the slight tendency of Ink $4 \mathrm{a}^{+/-}$mice to develop more PSA compared to $\mathrm{HDGF}^{\mathrm{Tyr}} / \mathrm{Ink} \mathrm{a}^{+/-}$mice was not statistical significant.

For histological analysis serial sections were HE stained or bleached before HE staining was performed to examine the pigmented areas in detail (Figure 4A). In addition, immunofluorescent staining was performed to asses HDGF-expression in PSA (Figure 4B). HE-stainings revealed that PSA did not resemble melanoma or melanocytic lesions, but rather represent pigmented epidermoid cysts, consisting of a lumen filled with keratinized material surrounded by an epithelial layer of keratinocytes. When comparing the bleached to the nonbleached HE stained sections, it can be noticed that there are only pigmented keratin fibres in the lumen, but no viable cells (yellow arrows Figure 4A). Melanocytes are only located next to the keratinocyte layer (green arrows Figure 4A).

Immunofluorescent staining revealed that both melanocytes and keratinocytes of the epidermoid cysts express HDGF (green arrows Figure 4B a, b, d, e). As expected, no HDGF-expression could be detected in epidermoid cysts derived from $\mathrm{HDGF}^{-/-} / \mathrm{Ink} \mathrm{4a}^{+/-}$mice. Notably, epidermoid cyst associated melanocytes from wildtype animals showed a strong HDGF staining (Figure $4 \mathrm{~B} \mathrm{~b}$ ), whereas melanocytes in healthy, untreated wildtype hair follicles express HDGF just to a very low extend (Figure 2A a).

In summary, neither melanocyte targeted HDGF-overexpression alone, nor in combination with a second genetic alteration and/or UVB-treatment, led to the development of melanocytic hyperplasia, or lesions in which differences in melanocyte number between the analyzed genotypes could be observed. Interestingly, not HDGF overexpression but HDGF-deficiency led to the development of an increased number and size of epidermoid cysts after UVB-treatment.

\section{Discussion}

HDGF was shown to be overexpressed in several types of tumors, like e.g. hepatocellular carcinoma $[17,18]$ or melanoma [23]. The correlation between the degree of HDGF overexpression, disease prognosis $[16,18,20-22,24]$ and the role for HDGF in tumor angiogenesis $[25,26]$, metastasis $[19,26]$, and apoptosis $[27,28]$ suggested that HDGF may function as an oncogene/protooncogene. In this study, a mouse model was generated to address the question whether HDGF-overexpression mediates oncogenic/transforming capacity to non-transformed cells in vivo. We chose to target the HDGF expression to melanocytes with the help of a Tyrosinase promoter/enhancer element (Figure 1A) since results presented by Bernard and co-workers revealed HDGFexpression in melanomas whereas HDGF was absent or weakly present in nontumorigenetic melanocytes [23]. In addition, HDGF-expression was graded with progression, suggesting that the frequency of HDGF-expression increases from benign nevi gradually to late melanoma stages [23]. Therefore, if HDGF exhibits oncogenic/ transforming capacity on melanocytes, loss or overexpression of HDGF are expected to have an influence on tumor development and/or progression.

Transgene induced HDGF overexpression in melanocytes could be confirmed by comparing melanocytes 


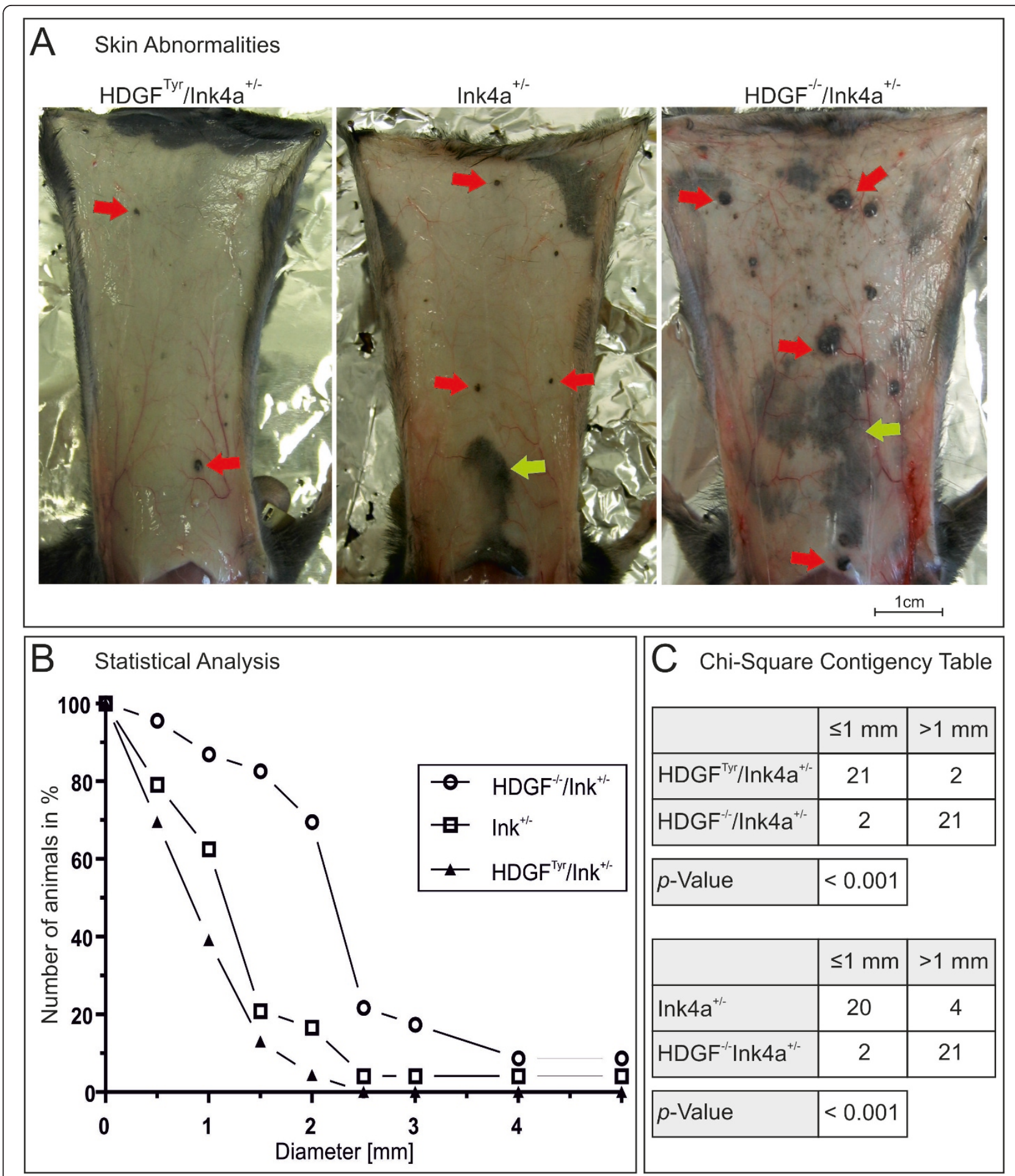

Figure 3 Statistical analysis of pigmented skin abnormalities (PSA). A: Overview of the inner side of skins from $\mathrm{HDGF}^{\mathrm{Tyr}} / \mathrm{Ink}^{\mathrm{Ha}}{ }^{+/}$, Ink4a ${ }^{+/}$, and $\mathrm{HDGF}^{-/} / \mathrm{Ink}_{4} \mathrm{a}^{+-}$mice showing PSA. Scale bar equates $1 \mathrm{~cm}$. B: Statistical analysis of the occurrence of (PSA) of the different genotypes. $\mathrm{HDGF}^{\mathrm{Tyr}} / \mathrm{Ink} 4 \mathrm{a}^{+/} \mathrm{n}=23, \mathrm{Ink} 4 \mathrm{a}^{+/} \mathrm{n}=24 ; \mathrm{HDGF}^{-/} / \mathrm{Ink} \mathrm{a}^{+/-} \mathrm{n}=23$. C: Chi-square contingency table was applied for the category: largest PSA was $\leq 1 \mathrm{~mm}$ or $>1 \mathrm{~mm}$. Contingency tables were carried out for the following pairs of genotypes: HDGF ${ }^{\mathrm{Tyr}} / \mathrm{Ink} \mathrm{a}^{+/-}-\mathrm{HDGF}^{-/-} / \mathrm{Ink} \mathrm{a}^{+/-}$and Ink4a $\mathrm{a}^{+/-}$$\mathrm{HDGF}^{-1} / \mathrm{Ink}_{4 \mathrm{a}}{ }^{+-}$. Analysis was regarded significant for $\mathrm{p}<0.01$. 


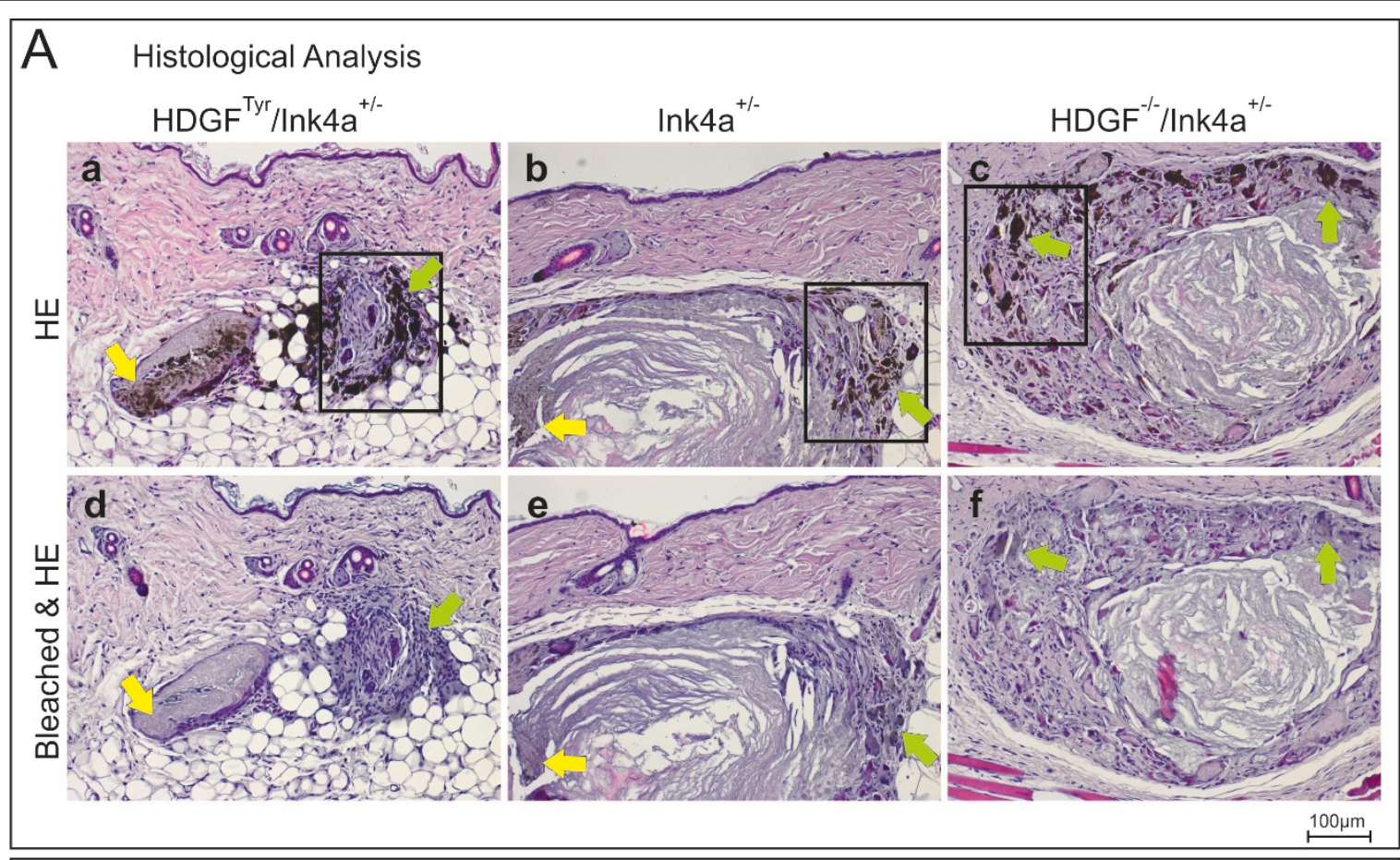

B Immunofluorescence Of Epidermoid Cysts

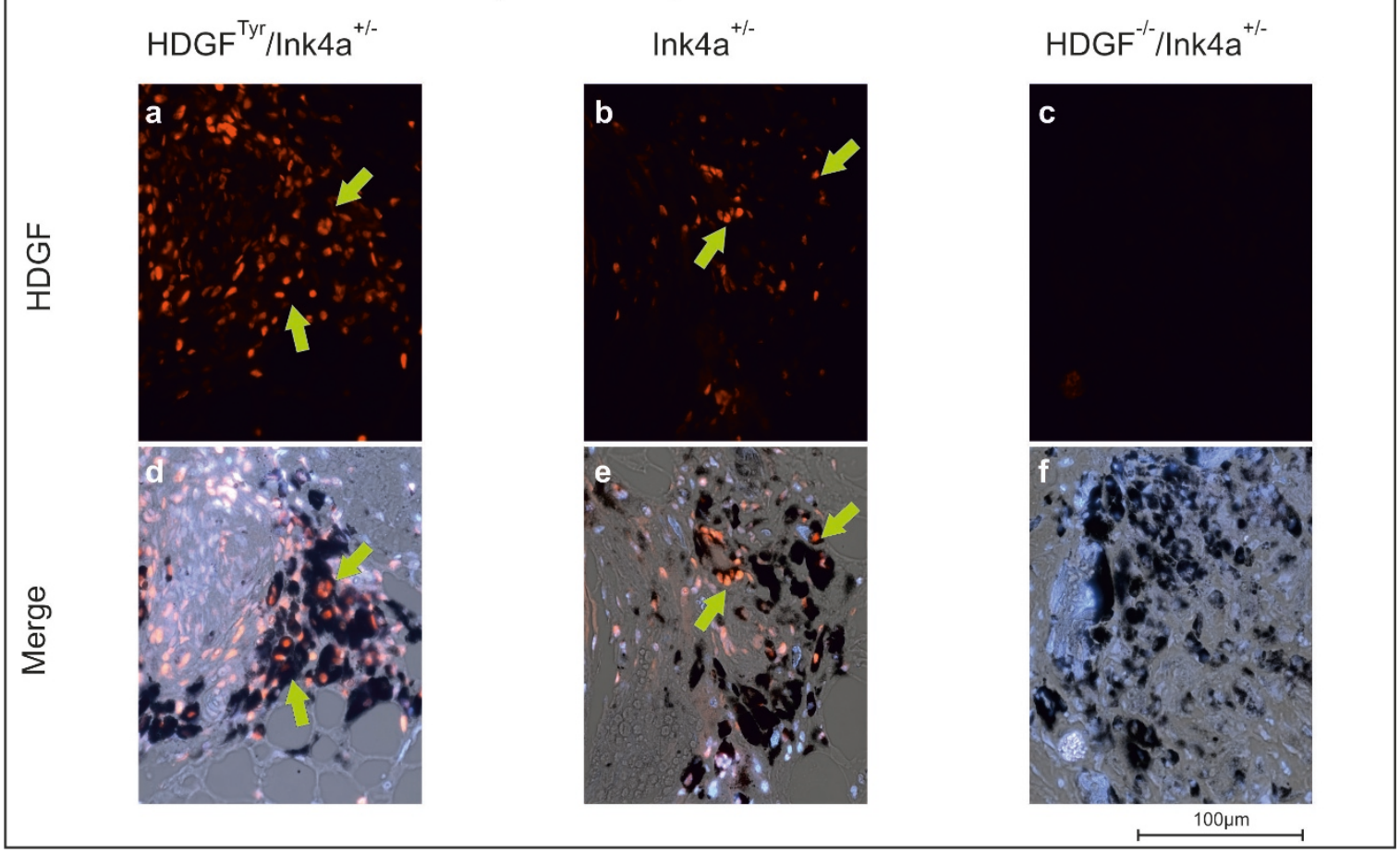

Figure 4 Histological analysis of pigmented skin abnormalities (PSA). A: Serial sections of PSA were either directly HE stained (a-c) or bleached in a benzylalcohol/aceton/ $/ \mathrm{H}_{2} \mathrm{O}_{2}$ based bleaching solution before HE-staining was performed ( $\mathrm{d}-\mathrm{f}$ ). Yellow arrows point to the pigmented and to the bleached areas respectively within the cyst lumen; green arrows point to pigmented and bleached melanocytes respectively. B: Immunofluorescence of epidermoid cysts. HDGF was detected by incubation with anti-mouse HDGF antibody and Cy3conjugated goat-anti-rabbit antibody (a-f). Nuclei were stained with DAPI. a-c HDGF; d-f merge of HDGF, DAPI and transmitted light. Green arrows point to HDGF-positive nuclei in pigmented areas. Scale bars equate $100 \mu \mathrm{m}$. 
and tissues of wildtype and $\mathrm{HDGF}^{\mathrm{Tyr}} / \mathrm{HDGF}^{-/-}$mice (Figure 2, Additional file 1). No alterations regarding melanocyte number and localization could be observed in vivo in $\mathrm{HDGF}^{\mathrm{Tyr}}$, wildtype and $\mathrm{HDGF}^{-/-}$mice, which were additionally analyzed to investigate whether the HDGF-deficiency has an impact on melanocytes in the further conducted experiments. To favor the development of tumors we introduced a second genetic alteration and applied an additional mutagenic noxa. This was done by deleting one copy of the Ink4a tumor suppressor gene and exposure to mutagenic doses of UV-light. Neonatal sunburn of $\mathrm{HDGF}^{\mathrm{Tyr}} / \mathrm{Ink}_{4 \mathrm{a}^{+/-}}$, Ink $4 \mathrm{a}^{+/-}$, and $\mathrm{HDGF}^{-/-} / \mathrm{Ink} 4 \mathrm{a}^{+/-}$mice led to the development of pigmented skin abnormalities (Figure 3). These abnormalities, however, did not resemble melanocytic lesions, but strongly resembled human epidermoid cysts. These cysts are benign, round or oval in shape, are in contact with the skin surface via a pore, and are confined by a squamous epithelium which, through cornification, produces a perl of keratinized material [41]. Epidermoid cysts arise most frequently from the infundibulum of hair follicles and represent a keratinocyte differentiation defect. Pigmentation of epidermaoid cysts follows a definite anatomic pattern and is dependent in humans on the natural skin color $[42,43]$. No differences regarding pigmentation of murine epidermoid cysts of $\mathrm{HDGF}^{\mathrm{Tyr}}$ / Ink $4 \mathrm{a}^{+/-}$, Ink $4 \mathrm{a}^{+/-}$, or $\mathrm{HDGF}^{-/-} / \operatorname{Ink} 4 \mathrm{a}^{+/-}$mice could be observed. Therefore, melanocytes located at the squamous epithelium of epidermoid cysts seem to derive from follicular melanocytes and the observed increased number of melanocytes may be due to growth factors released from cells of the benign cysts. Detailed analysis of size and number of epidermoid cyst per animal revealed a difference between the genotypes. Thus, $\mathrm{HDGF}^{-/-} / \mathrm{Ink}_{4 \mathrm{a}}{ }^{+/-}$mice developed significantly more and larger epidermoid cysts compared to both $\mathrm{HDGF}^{\mathrm{Tyr}}$ / Ink $4 \mathrm{a}^{+/-}$and Ink $4 \mathrm{a}^{+/-}$mice (Figure 3A-C). Morphologically keratinocytes of the outer root sheat (ORS) resemble keratinocytes of the basal cell layer with which they form a continuous cell layer. The morphology of epidermoid cysts indicate that ORS keratinocytes run through the differentiation program of epidermal keratinocytes [44] resulting in the formation of a perl of keratinized material. It is not clear why Ink $4 \mathrm{a}^{+/-}$mice develop epidermoid cysts after a single neonatal UVB-treatment, but our results show that additional HDGF-deficiency leads to more and larger epidermoid cysts. The presented results therefore indicate that HDGF in wildtype mice is involved in the control of keratinocyte differentiation. So far, HDGF was reported to promote differentiation of e.g. vascular smooth muscle cells $[5,45,46]$. In addition, Enomoto and coworkers recently reported on the investigation of an albumin-HDGF transgenic mouse model targeting HDGF-overexpression to hepatocytes
[47]. In this case the overexpression of HDGF resulted in delayed hepatocyte maturation, suggesting that HDGF-overexpression in hepatocytes partially suppresses hepatocyte differentiation. In contrast, delayed melanocyte maturation in $\mathrm{HDGF}^{\mathrm{Tyr}}$ mice was not obvious since skin and hair pigmentation of neonatal HDGF $^{\text {Tyr }}$ mice was indistinguishable from wildtype littermates. The only hint on an impact of elevated HDGF-levels on melanocyte differentiation came from in vitro experiments. When we tried to culture primary melanocytes from $\mathrm{HDGF}^{\mathrm{Tyr}}$, wildtype and $\mathrm{HDGF}^{-/-}$newborn mice, $\mathrm{HDGF}^{\mathrm{Tyr}}$ melanocytes were not able to differentiate and grow in a confluent pigmented cell layer (Figure 2B).

In conclusion, the results obtained here implicate that HDGF does not convey an oncogenic/transforming capacity to melanocytes. In fact, our results and those from other groups point to an involvement of HDGF in cell differentiation. Nevertheless, the overexpression of HDGF in various tumors and its validity as a prognostic marker in some tumors points to a significant role of this growth factor. Over the last years, the concept of non-oncogene addiction (NOA) was established. This concept describes the fact that tumors depend on the expression or overexpression of several proteins, which are not oncogenes, but which are secondarily regulated and thus promote tumor progression [48]. These proteins, like e.g. Stat5 or HSF1, help tumor cells to overcome cellular stress which in normal cells would lead to apoptosis $[49,50]$. In case of HSF1-deprivation tumor cells die and tumors regress whereas normal cells do not depend on this protein [51]. The latter certainly applies for HDGF as shown by the normal development and health of $\mathrm{HDGF}^{-/-}$mice [15]. On the other hand, in vitro and in vivo experiments showed that a reduction of HDGF in transformed cells or the injection of HDGF specific antibodies resulted in slowed tumor growth, reduced number of blood vessels, and increased rate of apoptosis [25,52-54]. These results and the results of this study strongly suggest that HDGF does not possess oncogenic/transforming capacities. Instead our results and the results from other groups made us realize that HDGF exhibits many criteria to fit into the concept of non-oncogene addiction. This recommends HDGF as a potential drug target with relevance for a variety of tumors.

\section{Conclusions}

In summary, we developed an animal model overexpressing HDGF in melanocytes. Our results provide no evidence that HDGF has a direct transforming role in tumor development. Instead, the here presented results in combination with previous findings point to a possible role of the growth factor in cell differentiation and 
suggest that HDGF promotes tumor progression after secondary upregulation. Therefore, HDGF may represent another protein fitting into the concept of nononcogene addiction of tumor tissue, supporting the assumption of other research groups that HDGF could serve as a target for cancer drug development.

\section{Additional material}

\section{Additional file 1: Expressional analysis of the Tyrosinase-}

HDGFgeneConstruct. A: Expression of the HDGFgene construct. Lysates of HEK cells transfected with HDGFcdspCDNA3, HDGFgenepBEH or Mock $(\mathrm{pBEH})$ were separated by SDS-gel electrophoresis. HDGF protein expression could be detected in samples transfected with

HDGFcdspCDNA3 and HDGFgenepBEH. B: Western blot analysis of brain lysates. Brain lysates from wildtype, $\mathrm{HDGF}^{\mathrm{Ty}}$, $\mathrm{HDGF}^{-1 /}$ and $\mathrm{HDGF}^{\mathrm{Tyr}}$ / $\mathrm{HDGF}^{-1-}$ mice were analysed. HDGF could be detected in wildtype, $\mathrm{HDGF}^{\mathrm{Tyr}}$ and $\mathrm{HDGF}^{\mathrm{Tyr}} / \mathrm{HDGF}^{-/}$(white arrow) brain lysates. C: Detection of HDGF-mRNA in mouse tissue. Total HDGF-mRNA was detected by performing RT-PCR on CDNA from wildtype and $\mathrm{HDGF}^{\text {Tyr }}$ tissues using primers spanning the complete HDGF coding sequence (HDGF-sense/ HDGF-antisense). The amplificated HDGF-mRNA could be detected as a 841 bp fragment in all samples (lane 1, 3, 5, 7, 9, and 11). Tyr-HDGFmRNA expressed from the Tyrosinase-HDGFgene construct could only be detected in samples from the transgenic animal (red arrows; $861 \mathrm{bp}$ fragment in lane 4, 8, and 12).

Additional file 2: In Situ Hybridisation (ISH) and hematoxylin/eosin (HE) staining of skin samples from $\mathrm{HDGF}^{\mathrm{Tyr}} / \mathrm{HDGF}^{-/,}, \mathrm{HDGF}^{-/}$, and wildtype mice. Paraffin sections were used to detect tyrosinase mRNA in melanocytes by incubating the sections with the digoxygenin labeled tyrosinase-antisense (Tyr as) probe or the tyrosinase-sense (Tyr s) probe as a control. Bound probe was detected by incubation with alkaline phosphatase coupled anti-digoxygenin Fab fragment. BM Purple was used as a substrate. a-c HE-staining; d-f ISH Tyr_as; g-i ISH Tyr_s. Scale bar equates $100 \mu \mathrm{m}$.

\section{Acknowledgements}

We thank Dr. Friedrich Beermann (ISREC, Epalinges, Switzerland) for kindly providing the tyrosinase promoter/enhancer element.

\section{Author details}

'Institute of Biochemistry and Molecular Biology, University of Bonn, Nussallee 11, 53115 Bonn, Germany. Institute of Pathology, University Hospital Bonn, Bonn, Germany. ${ }^{3}$ Faculty of Pharmacy, University of El-Minia, Minia, Egypt.

\section{Authors' contributions}

AS and RG developed the animal models. AS and MA carried out the experiments. NW participated in the statistical analysis of tissue samples. VG participated in study design and drafted the manuscript. SF supervised the study, took part in sample analysis and study design. AS and SF drafted the manuscript. All authors read and approved the final manuscript.

\section{Competing interests}

The authors declare that they have no competing interests.

Received: 9 June 2011 Accepted: 20 October 2011

Published: 20 October 2011

\section{References}

1. Nakamura H, Izumoto Y, Kambe H, Kuroda T, Mori T, Kawamura K, Yamamoto H, Kishimoto T: Molecular cloning of complementary DNA for a novel human hepatoma-derived growth factor. Its homology with high mobility group-1 protein. J Biol Chem 1994, 269(40):25143-25149.
2. Nakamura H, Kambe H, Egawa T, Kimura Y, Ito H, Hayashi E, Yamamoto H, Sato J, Kishimoto S: Partial purification and characterization of human hepatoma-derived growth factor. Clin Chim Acta 1989, 183(3):273-284.

3. Abouzied MM, El-tahir HM, Prenner L, Haberlein H, Gieselmann V, Franken S: Hepatoma-derived Growth Factor:Significance of Amino Acid Residues 81-100 in Cell Surface Interaction and Proliferative Activity. J Biol Chem 2005, 280(12):10945-10954.

4. Everett AD, Bushweller J: Hepatoma derived growth factor is a nuclear targeted mitogen. Curr Drug Targets 2003, 4(5):367-371.

5. Everett AD, Stoops T, McNamara CA: Nuclear targeting is required for hepatoma-derived growth factor-stimulated mitogenesis in vascular smooth muscle cells. J Biol Chem 2001, 276(40):37564-37568.

6. Kishima $Y$, Yamamoto $H$, Izumoto $Y$, Yoshida $K$, Enomoto $H$, Yamamoto $M$, Kuroda T, Ito H, Yoshizaki K, Nakamura H: Hepatoma-derived growth factor stimulates cell growth after translocation to the nucleus by nuclear localization signals. J Biol Chem 2002, 277(12):10315-10322.

7. Abouzied MM, Baader SL, Dietz F, Kappler J, Gieselmann V, Franken S: Expression patterns and different subcellular localization of the growth factors HDGF (hepatoma-derived growth factor) and HRP-3 (HDGFrelated protein-3) suggest functions in addition to their mitogenic activity. Biochem J 2004, 378(Pt 1):169-176.

8. Enomoto H, Yoshida K, Kishima Y, Kinoshita T, Yamamoto M, Everett AD Miyajima A, Nakamura $\mathrm{H}$ : Hepatoma-derived growth factor is highly expressed in developing liver and promotes fetal hepatocyte proliferation. Hepatology 2002, 36(6):1519-1527.

9. Oliver JA, Al-Awqati Q: An endothelial growth factor involved in rat renal development. J Clin Invest 1998, 102(6):1208-1219.

10. Nakamura H, Yoshida K, Ikegame K, Kishima Y, Uyama H, Enomoto H: Antibodies against hepatoma-derived growth factor and mucosal repair in ulcerative colitis. J Gastroenterol 2002, , 37 Suppl 14: 8-14.

11. Nakamura H, Yoshida K, Kishima Y, Enomoto H, Uyama H, Kuroda T, Okuda Y, Hirotani T, Ito H, Kawase I: Circulating auto-antibody against hepatoma-derived growth factor (HDGF) in patients with ulcerative colitis. Hepatogastroenterology 2004, 51(56):470-475.

12. Narron JV, Stoops TD, Barringhaus K, Matsumura M, Everett AD: Hepatomaderived growth factor is expressed after vascular injury in the rat and stimulates smooth muscle cell migration. Pediatr Res 2006, 59(6):778-783.

13. Bianchi ME: DAMPs, PAMPs and alarmins: all we need to know about danger. J Leukoc Biol 2007, 81(1):1-5.

14. Zong WX, Thompson CB: Necrotic death as a cell fate. Genes Dev 2006, 20(1):1-15.

15. Gallitzendoerfer R, Abouzied MM, Hartmann D, Dobrowolski R, Gieselmann V, Franken S: Hepatoma-derived growth factor (HDGF) is dispensable for normal mouse development. Dev Dyn 2008, 237(7):1875-1885.

16. Ren H, Tang X, Lee JJ, Feng L, Everett AD, Hong WK, Khuri FR, Mao L: Expression of Hepatoma-Derived Growth Factor Is a Strong Prognostic Predictor for Patients With Early-Stage Non-Small-Cell Lung Cancer. J Clin Oncol 2004, 22(16):3230-3237.

17. Hu TH, Huang CC, Liu LF, Lin PR, Liu SY, Chang HW, Changchien CS, Lee CM, Chuang JH, Tai MH: Expression of hepatoma-derived growth factor in hepatocellular carcinoma. Cancer 2003, 98(7):1444-1456.

18. Yoshida $\mathrm{K}$, Tomita $\mathrm{Y}$, Okuda $\mathrm{Y}$, Yamamoto $\mathrm{S}$, Enomoto $\mathrm{H}$, Uyama $\mathrm{H}$, Ito $\mathrm{H}$, Hoshida Y, Aozasa K, Nagano H, Sakon M, Kawase I, Monden M, Nakamura H: Hepatoma-derived growth factor is a novel prognostic factor for hepatocellular carcinoma. Ann Surg Oncol 2006, 13(2):159-167.

19. Lepourcelet M, Tou L, Cai L, Sawada J-i, Lazar AJF, Glickman JN, Williamson JA, Everett AD, Redston M, Fox EA, Nakatani Y, Shivdasani RA: Insights into developmental mechanisms and cancers in the mammalian intestine derived from serial analysis of gene expression and study of the hepatoma-derived growth factor (HDGF). Development 2005, 132(2):415-427.

20. Yamamoto S, Tomita Y, Hoshida Y, Takiguchi S, Fujiwara Y, Yasuda T, Doki Y, Yoshida K, Aozasa K, Nakamura H, Monden M: Expression of HepatomaDerived Growth Factor Is Correlated with Lymph Node Metastasis and Prognosis of Gastric Carcinoma. Clin Cancer Res 2006, 12(1):117-122.

21. Yamamoto S, Makuuchi H, Shimada H, Chino O, Nishi T, Kise Y, Kenmochi T, Hara T: Clinical analysis of reflux esophagitis following esophagectomy with gastric tube reconstruction. J Gastroenterol 2007, 42(5):342-345.

22. Uyama H, Tomita Y, Nakamura H, Nakamori S, Zhang B, Hoshida Y, Enomoto H, Okuda Y, Sakon M, Aozasa K, Kawase I, Hayashi N, Monden M: 
Hepatoma-derived growth factor is a novel prognostic factor for patients with pancreatic cancer. Clin Cancer Res 2006, 12(20 Pt 1):6043-6048.

23. Bernard K, Litman E, Fitzpatrick JL, Shellman YG, Argast G, Polvinen $K$, Everett AD, Fukasawa K, Norris DA, Ahn NG, Resing KA: Functional proteomic analysis of melanoma progression. Cancer Res 2003, 63(20):6716-6725.

24. Hu TH, Lin JW, Chen HH, Liu LF, Chuah SK, Tai MH: The expression and prognostic role of hepatoma-derived growth factor in colorectal stromal tumors. Dis Colon Rectum 2009, 52(2):319-326.

25. Ren H, Chu Z, Mao L: Antibodies targeting hepatoma-derived growth factor as a novel strategy in treating lung cancer. Mol Cancer Ther 2009, 8(5):1106-1112.

26. Zhang J, Ren H, Yuan P, Lang W, Zhang L, Mao L: Down-regulation of Hepatoma-Derived Growth Factor Inhibits Anchorage-Independent Growth and Invasion of Non-Small Cell Lung Cancer Cells. Cancer Res 2006, 66(1):18-23.

27. Machuy N, Thiede B, Rajalingam K, Dimmler C, Thieck O, Meyer TF, Rudel T: A Global Approach Combining Proteome Analysis and Phenotypic Screening with RNA Interference Yields Novel Apoptosis Regulators. Mol Cell Proteomics 2005, 4(1):44-55.

28. Shen $X Y$, Zacal N, Singh G, Rainbow AJ: Alterations in mitochondrial and apoptosis-regulating gene expression in photodynamic therapy-resistant variants of HT29 colon carcinoma cells. Photochem Photobiol 2005, 81(2):306-313.

29. Serrano M, Lee H, Chin L, Cordon-Cardo C, Beach D, DePinho RA: Role of the INK4a locus in tumor suppression and cell mortality. Cell 1996, 85(1):27-37.

30. Bancroft JDaC, H C: Manual of histological techniques and their diagnostic application. Churchill Livingstone 1994.

31. Fewou SN, Bussow H, Schaeren-Wiemers N, Vanier MT, Macklin WB, Gieselmann V, Eckhardt M: Reversal of non-hydroxy:alpha-hydroxy galactosylceramide ratio and unstable myelin in transgenic mice overexpressing UDP-galactose:ceramide galactosyltransferase. J Neurochem 2005, 94(2):469-481.

32. Harlow E, Lane D: Antibodies: a laboratory manual. Cold Spring Habor, NY: Cold Spring Habor Laboratory Press; 1988.

33. Beermann F, Schmid E, Ganss R, Schutz G, Ruppert S: Molecular characterization of the mouse tyrosinase gene: pigment cell-specific expression in transgenic mice. Pigment Cell Res 1992, 5(5 Pt 2):295-299.

34. Tief $K$, Hahne M, Schmidt A, Beermann F: Tyrosinase, the key enzyme in melanin synthesis, is expressed in murine brain. Eur J Biochem 1996, 241(1):12-16.

35. Tief K, Schmidt A, Aguzzi A, Beermann F: Tyrosinase is a new marker for cell populations in the mouse neural tube. Dev Dyn 1996, 205(4):445-456.

36. Tief K, Schmidt A, Beermann F: Regulation of the tyrosinase promoter in transgenic mice: expression of a tyrosinase-lacZ fusion gene in embryonic and adult brain. Pigment Cell Res 1997, 10(3):153-157.

37. Chin L, Pomerantz J, Polsky D, Jacobson M, Cohen C, Cordon-Cardo C, Horner JW, DePinho RA: Cooperative effects of INK4a and ras in melanoma susceptibility in vivo. Genes Dev 1997, 11(21):2822-2834.

38. Kelsall SR, Mintz B: Metastatic cutaneous melanoma promoted by ultraviolet radiation in mice with transgene-initiated low melanoma susceptibility. Cancer Res 1998, 58(18):4061-4065.

39. Noonan FP, Recio JA, Takayama H, Duray P, Anver MR, Rush WL, De Fabo EC, Merlino G: Neonatal sunburn and melanoma in mice. Nature 2001, 413(6853):271-272

40. Thomas J, Liu T, Cotter MA, Florell SR, Robinette K, Hanks AN, Grossman D: Melanocyte expression of survivin promotes development and metastasis of UV-induced melanoma in HGF-transgenic mice. Cancer Res 2007, 67(11):5172-5178.

41. Grote W, Lund OE: Observations on pathogenesis of an unusual intraspinal epidermoid. Dtsch Z Nervenheilkd 1957, 176(1):48-54.

42. Sandoval R, Urbina F: Pigmented follicular cyst. Br J Dermatol 1994, 131(1):130-131.

43. Shet T, Desai S: Pigmented epidermal cysts. Am J Dermatopathol 2001, 23(5):477-481.

44. Lippens $\mathrm{S}$, Hoste E, Vandenabeele P, Agostinis P, Declercq W: Cell death in the skin. Apoptosis 2009, 14(4):549-569.

45. Everett AD, Lobe DR, Matsumura ME, Nakamura H, McNamara CA: Hepatoma-derived growth factor stimulates smooth muscle cell growth and is expressed in vascular development. I Clin Invest 2000, 105(5):567-575.

46. Everett AD, Narron JV, Stoops T, Nakamura H, Tucker A: Hepatoma-derived growth factor is a pulmonary endothelial cell-expressed angiogenic factor. Am J Physiol Lung Cell Mol Physiol 2004, 286(6):L1194-1201.

47. Enomoto H, Nakamura H, Komatsu-Kanatani N, Liu Y, Yoshida K, Okuda Y, Yamamoto T, Liu W, Nishiguchi S: Partial blockage of hepatocyte maturation in hepatoma-derived growth factor transgenic mice. World J Hepatol 2009, 1(1):98-102.

48. Hoelbl A, Schuster C, Kovacic B, Zhu B, Wickre M, Hoelzl MA, Fajmann S, Grebien F, Warsch W, Stengl G, Hennighausen L, Poli V, Beug H, Moriggl R, Sexl V: Stat5 is indispensable for the maintenance of bcr/abl-positive leukaemia. EMBO Mol Med 2010, 2(3):98-110.

49. Fulda S: Tumor resistance to apoptosis. Int J Cancer 2009, 124(3):511-515.

50. Luo J, Solimini NL, Elledge SJ: Principles of cancer therapy: oncogene and non-oncogene addiction. Cell 2009, 136(5):823-837.

51. Solimini NL, Luo J, Elledge SJ: Non-oncogene addiction and the stress phenotype of cancer cells. Cell 2007, 130(6):986-988.

52. Liao F, Dong W, Fan L: Apoptosis of human colorectal carcinoma cells is induced by blocking hepatoma-derived growth factor. Med Oncol 2009, 27(4):1219-1226.

53. Tsang TY, Tang WY, Tsang WP, Co NN, Kong SK, Kwok TT: Downregulation of hepatoma-derived growth factor activates the Bad-mediated apoptotic pathway in human cancer cells. Apoptosis 2008, 13(9):1135-1147.

54. Tsang TY, Tang WY, Tsang WP, Co NN, Kong SK, Kwok TT: Mechanistic study on growth suppression and apoptosis induction by targeting hepatoma-derived growth factor in human hepatocellular carcinoma HepG2 cells. Cell Physiol Biochem 2009, 24(3-4):253-262.

\section{Pre-publication history}

The pre-publication history for this paper can be accessed here: http://www.biomedcentral.com/1471-2407/11/457/prepub

doi:10.1186/1471-2407-11-457

Cite this article as: Sedlmaier et al:: Overexpression of hepatomaderived growth factor in melanocytes does not lead to oncogenic transformation. BMC Cancer 2011 11:457.

\section{Submit your next manuscript to BioMed Central and take full advantage of:}

- Convenient online submission

- Thorough peer review

- No space constraints or color figure charges

- Immediate publication on acceptance

- Inclusion in PubMed, CAS, Scopus and Google Scholar

- Research which is freely available for redistribution

Submit your manuscript at www.biomedcentral.com/submit
C Biomed Central 